\title{
A Constructivist Perspective on Leadership Thought among Brazilian and North-American Scholars
}

Anderson de Souza Sant'Anna * E-mail address: anderson@fdc.org.br

Fundação Dom Cabral

Nova Lima, MG, Brazil.

Samir Lotfi

E-mail address: samir@fdc.org.br

Fundação Dom Cabral

Nova Lima, MG, Brazil

Reed Elliot Nelson

E-mail address: renelson@siu.edu Southern Illinois University at Carbondale

Carbondale, IL, USA.

Marly Sorel Campos E-mail address: msorel@fdc.org.br

Fundação Dom Cabral

Nova Lima, MG, Brazil

Jordan Nassif Leonel

E-mail address: jordan@fdc.org.br

Fundação Dom Cabral

Nova Lima, MG, Brazil

* Corresponding author: Anderson de Souza Sant'Anna

Av. Princesa Diana, 760, Alphaville, Lagoa dos Ingleses, Nova Lima, MG, 34000-000, Brazil.

Copyright (C) 2011 Brazilian Administration Review. All rights reserved, including rights for translation. Parts of this work may be quoted without prior knowledge on the condition that the source is identified. 


\begin{abstract}
This paper presents the results of an exploratory, inductive cataloguing of the views of Brazilian and U.S. academics regarding current leadership theory and development. Semi structured interviews with academics from a variety of institutional settings in Brazil and the U.S. were content analyzed to identify major themes and tendencies across the two countries. Our analyses revealed that neither Brazilian nor U.S. academics adopted the bulk of current formal leadership thought uncritically. Instead, both the Brazilian and North American business education fields adopted theories selectively and formulated idiosyncratic approaches to the field. The U.S. interviewees appeared to vary much more from one another than the Brazilian scholars, whose positions were more critical but more homogeneous overall. There was also considerable variation across the two national settings. We found Bourdieu's practice theory useful in interpreting our results, particularly the concepts of field differentiation and heteronomy, habitus, and cultural capital. Still, much research remains to be done to disentangle the purely historical and cultural factors from the impacts of the social construction of the field of business education in the two countries.
\end{abstract}

Key words: leadership; Bourdieu; comparative management; leadership development. 


\section{Introduction}

Leadership is one of the most complex and multifaceted phenomena investigated in research on human behavior (Seters \& Field, 1990), and the quest to identify factors associated with effective leadership (Higgs, 2003) has been on for decades. A broad range of theoretical propositions and approaches that aim to understand this phenomenon can be found, and their frequency and diversity have increased geometrically since the second half of the $20^{\text {th }}$ century. Despite the proliferation of studies and analyses of practically every facet of human behavior imaginable in the post modern world, as recently as 2002 Goffe and Jones alleged that the volume of research on leadership still surpasses that of any other human behavior topic.

Despite - or perhaps because of - intensive empirical inquiry and theoretical development dating back over half a century, there is little consensus concerning definitions, theories and normative prescriptions in the leadership literature (Stout, 2001). This dissensus is likely to increase as new demands are placed on leaders and theories of leadership along with increasing rates of change and volatility of the environment in the $21^{\text {st }}$ century. Among factors that will bring greater complexity to the field of leadership are changes in societal and personal values, changing relationships between organizations and their various stakeholders, increasing globalization and multiculturalism, as well as demands emerging from new roles companies must play in society (Higgs, 2003). These and other changes will require more complex leadership practices as organizations' configurations become more organic and adaptable and thus present multiple communication flows as well as new links and relations at the interface between subject, work, organizations and society (Burns \& Stalker, 1961).

It is probably safe to predict that Brazilian society and institutions will be as heavily influenced by evolving leadership demands as other countries. Indeed, there is ample evidence that Brazilian managers are already perceiving a significant leadership deficit and growing complexity in the demands placed on current leaders (Milagres, 2005). It is equally likely that the Brazilian academic community, as in other countries, will play some role in developing and conveying ideas about how the leadership challenges of the $21^{\text {st }}$ century can be met.

The central purpose of this paper is to present the results of a field study describing the reactions of prominent Brazilian academics to current leadership theory, challenges and development, and contrasting these reactions to a roughly comparable group of North American academics. Although there is some inherent intellectual value in simply cataloguing these reactions, our ambitions go somewhat beyond a simple descriptive exercise. We also hope to gain some insight into how leadership studies in Brazil and the United States constitute socially constructed fields and in what ways these fields are similar or different.

\section{On the application of practice theory to leadership studies}

Twentieth century constructivists - most notably Pierre Bourdieu, but also Bruno Latour, Anthon Giddens, and others - argued that the activities of scientists of all types - including behavioral scientists - are not exercises in pure rationality. Rather, they involve complex webs of social relations where actors develop strategies, cultural capital and habitus which constitute a field of practice. These strategies, capital and habitus serve to locate actors within a field and to both stabilize as well as challenge the distribution of power, status and resources within the field (Bourdieu, 1977, 1993, 1998).

We find this perspective particularly promising for the study of leadership because of the inherent complexity and dissensus in the field as well as the increasing dynamism of the practice of leadership resulting from the environmental factors mentioned above. Given this volatile context, we find it highly unlikely that any one scholar or community of scholars in the field of leadership will: (a) Pay equal attention to all of the theories espoused in the orthodox international management literature; (b) Uncritically accept the bulk of existing leadership thought; (c) Select ontologies and 
epistemologies that are uninfluenced by their position in national and international intellectual fields. By paying close attention to the constructivist implications of our informants' discourse, we hope to gain deeper insight into the social dynamics of the study of leadership in Brazil and, secondarily, in the United States, and to offer our own critical perspective on the dynamics of the field.

Given this analytical agenda, we have divided our paper into three main sections. We first present a succinct review of the major trends in the leadership literature to date. This will provide a backdrop against which to compare the perceptions and orientations of the academics under study. Second, we will describe the methodological basis for our study and present the principal themes that surfaced through a content analysis of our interviews. Third, we will interpret our results in the light of the constructivist principles alluded to above. In closing, we will pose questions and challenges to the field that follow from our findings.

\section{Literature Review}

\section{The evolution of orthodox leadership theory}

In historical terms, the first major theoretical framework of scientific studies on leadership can be traced to seminal works developed in the $19^{\text {th }}$ century. These works aimed to identify the characteristics and attributes of great personalities who would serve as exemplars for would- be leaders to emulate (Carlyle, 1842; Seters \& Field, 1990). This framework was later denominated Trait Theory and it focused on the formulation of lists of general personality dimensions which, if they were developed, would increase leadership potential (Seters \& Field, 1990). The theory was broadly adopted up to the mid 1940s, and some studies registered over 30 traits that were thought to be typical of effective leaders (Bergamini, 1994). Within the context of the Second World War a broad range of research work was carried out to find out which of these leadership traits were most effective. However, the results did not lead to a consensus (Stogdill, 1950).

Subsequent studies carried out in the 1950s and 1960s changed their focus to what leaders do (i.e., behaviors) rather than searching for ideal attributes (traits). These studies were shown to have greater practical potential and empirical support, as they sought to identify leadership behaviors that would favor effectiveness within institutions (Horner, 1997). The pioneering behavioral studies were associated with Ohio State and Michigan universities (USA), and this approach quickly grew in importance, especially because of its promise for linking leadership behaviors with organizational effectiveness.

The Michigan and Ohio State scholars characterized leadership behaviors as falling on a continuum ranging from task to relationship orientation. This task-relations dichotomy became prominent for several decades. Initially it was presumed that the two dimensions were zero-sum, so that an increase in task emphasis would come at the expense of a decrease in relationship emphasis. However, in the 1960s several authors, beginning with Blake and Mouton (1964), began to dispute the assertion that task and relationship are negatively correlated. Blake and Mouton proposed the so-called Managerial Grid, a matrix which used the existing task relationship dichotomy, but rejected the assumption that a leader cannot simultaneously entertain high levels of both task and relationship orientation. The resulting styles are configured into five independent, non-mutually exclusive behavioral patterns that range from the extremes of liberal to authoritarian management.

An interesting peripheral development in leadership theory during the 1960s that foreshadowed constructivist perspectives were studies by McGregor (1966) affirming that a leader's implicit view of human nature determined both style and effectiveness. McGregor argued that leaders whose world view assumes that people are competent and creative (Theory Y) would enhance both individual development and organizational performance. McGregor's views were widely circulated but appear to have had little influence on subsequent theoretical and empirical work. 
The second half of the 1960s marked a turn toward contingency theories in management studies in general. The Life Cycle Theory of Leadership proposed by Hersey and Blanchard (1969), renamed Situational Theory (Graeff, 1983) nine years later. This was perhaps the most commercially successful leadership theory to date but it has had little impact in academic circles. The theories of the situational period match the style of the leader with a variety of contextual variables. In the case of situational leadership, follower maturity was seen as the most important contingency. In Fiedler's (1967) less popular but better validated model, team performance is moderated by leadership style, by the level of acceptance of the leader's authority by subordinates, by the degree of task structure and by the leader's formal authority. According to Fiedler, a task-oriented leadership would be more effective in situations where there is either low or high acceptance by subordinates, while relationship-based management is suggested in cases where there is moderate acceptance.

By applying the expectancy theory of motivation to leadership studies, House (1971) developed the so-called Path-Goal theory of leadership. House (1971) argued that leaders influence follower motivation by influencing two contingencies: (a) expectations concerning the gains stemming from a certain path or behavior that has been adopted; and (b) trust that such a path will lead to greater chances for success. According to this perspective, leaders must encourage positive expectations in their subordinates regarding both the objectives to be achieved and the way to achieve them.

Vroom and Yetton (1973) also proposed a contingency model of leadership which included leadership style and decision-making process variables. Similar situational research led to the currently popular Leader-Member Exchange Theory (LMX Theory) initially proposed by Dansereau, Graen and Haga (1975). This theory aims to explain how the nature of the relationship between leaders and subordinates will influence the leadership process (Graen \& Ulh-Bien, 1995; Horner, 1997). LMX theory proposes that leaders have core and peripheral subordinates who entertain different types of exchanges with the leader. The core subordinate develops affective ties and identification with the leader while the peripheral subordinates maintain a more distant and instrumental set of exchanges.

By the mid 1980s a certain skepticism surrounding the search for ideal models of leadership began to emerge, led by Meindl Erlich and Dukerich's (1985) classic paper The Romance of Leadership. These Anti-leadership or substitutes for leadership theorists (Schyns \& Bligh, 2007; Seters \& Field 1990; Stout, 2001) argued that the link between leadership and human performance is much more complex than prior research recognized. This perspective identified three core problems with previous studies: (a). ambiguity in defining the concept; (b). the issue of up to what point leadership impacts organizational performance; and (c). the consequences of the innumerable irrelevant criteria adopted in the leader selection and succession process (Pfeffer, 1987).

Perhaps partially in response to issues raised by the anti leadership perspective, subsequent research has shown greater sensitivity to the cultural and symbolic aspects of leadership. Several studies that were carried out beginning in the 1980s sought out a new line of investigation in which leadership was analyzed not only as an individual phenomenon or a construct restricted to the leadersubordinate dyad or even to small groups, but as being linked to organizational culture. Such frameworks originated from, and were broadly influenced by, a cadre of researchers who sought to understand the relationship between culture and organizational life (Martin, 2002; Schein, 1992; Trice \& Beyer, 1993), and they were greatly influenced by Japan's rise as a premier industrial power in the 1970s.

During this cultural turn in leadership studies, the variables analyzed moved from more measurable items like productivity and efficiency to more subjective ones such as expectations and values (Seters \& Field, 1990). This paved the way for a flurry of interest in charisma and charismatic leadership, a concept studied by early sociologists, especially Max Weber, but generally neglected in management thought (Nelson, 1993). Aside from providing a bridge to cultural and symbolic concerns, the concept of charisma was associated with revolutionary and visionary change, a theme many perceived to be neglected in leadership studies (Burns, 1978). 
Academic and practitioner interest in charisma and charismatic leaders was initially very strong and continues up to the present, but stories of the negative and even pathological impacts of some charismatic figures led to a backlash of papers and books expressing reservations about charismatic leadership (Howell \& Shamir, 2005; Shamir, House, \& Arthur, 1993; Stout, 2001). Major concerns centered around willfulness, hubris, authoritarianism, creation of dependence, suspension of critical thinking, loss of team identity on the part of followers, depletion of organizational assets and ethical lapses, among other less serious issues.

The most successful of currently espoused theories of leadership represents a creative if not entirely credible synthesis and reconciliation of several of the major themes and controversies of the past two decades or so. Bass and colleagues' transformational leadership theory identifies a leadership style which appears to accommodate creativity, change and vision without the liabilities of charisma and its accompanying personality cults (Bass \& Avolio, 1990; Judge \& Bono, 2000; Piccolo \& Colquitt, 2006).

The transformational leadership style (Gong, Huang, \& Fahr, 2009; Kirkman, Chen, Farh, Chen, \& Lowe, 2009; Ling, Simsek, Lubatkin, \& Veiga, 2008) is believed to bring together four characteristics: (a) Idealized influence; (b) Inspirational Motivation; (c) Individualized consideration; (d) Intellectual stimulation. Idealized influence, which involves articulating a shared vision, and inspirational motivation are associated with traditional notions of charisma. However, individual consideration and intellectual stimulation go beyond charisma to include dimensions that are somewhat new to leadership theory. The transformational leader is contrasted with the transactional leader who motivates subordinates thorough more utilitarian exchanges and incentives.

By contrasting transformational leadership with transactional leadership, Bass and colleagues implicitly set their theory off against the earlier rationalistic leadership theories such as path-goal and LMX theories, while acknowledging at the same time the importance of subjective and symbolic factors and the importance of change and adaptation. Careful empirical research across different cultural settings has associated transformational leadership with employee creativity, productivity, entrepreneurial behavior and other desirable outcomes, lending considerable credibility to the concept (Bass \& Avolio, 1990; Gong et al., 2009; Judge \& Bono, 2000; Kirkman et al., 2009; Ling et al., 2008; Piccolo \& Colquitt, 2006). Not since Blake and Mouton's grid approach has a normative model of leadership without contingencies had so much influence.

Despite the dominance of transformational leadership theory, a number of alternative perspectives are still found in the literature and indeed their volume appears to be increasing. Most of these are closely associated with influential theories in one of the behavioral sciences. For instance, the general psychological theories of social identity and self regulation have each spawned their own leadership theories (Hogg, 2001; Kark \& Van Dijk, 2007). Similarly, the sociologist Keith Grint $(2001,2005)$ has advanced a theory of the leadership arts which is almost wholly based on the social construction of leadership and followership with only minimal reliance on objectivist thought. Lindholm (2009), out of anthropology, has a theory of charismatic leadership which relies heavily on political science and anthropological concepts and settings and invokes psychological and sociological views on charisma only sparingly. These various perspectives challenge and inform mainline leadership studies occasionally, but their influence is generally felt by way of the more dominant theories outlined above.

\section{Methodology}

As mentioned in our introduction, the purpose of this paper is both to catalogue Brazilian academic thinking on leadership at the beginning of the $21^{\text {st }}$ century, but also to encourage critical reflection about how the study of leadership functions as a socially constructed field. These objectives call for a grounded theory approach (Glaser \& Strauss, 1967) employing purposive sampling but 
minimizing limitations on the responses of our informants. In other words, given our research objectives, we wished to sample a rather broad range of academics and elicit a broad range of their views on leadership and its development without imposing our own analytical categories or a priori ideas on the participants. We therefore employed very broad, semi structured interviews which solicited the respondents' definition of the concept, their views on the major challenges, debates and studies, their reflections on the role of leaders in current and future organizations and their ideas on the teaching and development of leaders. The interview schedule is available from the authors. To avoid predisposing participants toward discussion of any particular theory or approach, the interview schedule did not mention or elicit responses regarding any specific leadership theory or author.

Purposive Sample. In Brazil, we conducted interviews with seventeen professors from the following institutions: Faculdade Novos Horizontes (FNH), Fundação Dom Cabral (FDC), Fundação Getúlio Vargas (FGV), Pontifícia Universidade Católica de Minas Gerais (PUC Minas), Universidade FUMEC, Universidade de São Paulo (USP) and Universidade Federal de Minas Gerais (UFMG). The Universidade de São Paulo and Fundação Getulio Vargas are the two most prominent academic business programs in the country and Fundação Dom Cabral is Brazil's foremost executive development and education entity. The other four institutions are prominent academic institutions in the state of Minas Gerais. UFMG is the region's largest public university and PUC Minas, the region's largest private one. FNH and FUMEC are another two of Minas Gerais' important private academic institutions. Our motivation was to access the most prominent thinking in the country on the topic while at the same time providing a range of institutional contexts and personal orientations.

In the United States we used the same interview schedule with seven scholars from American institutions - the University of Kentucky, Gatton College of Business and Economics, Washington University (St. Louis), Olin Business School, the University of Louisville, Purdue University North Central and Southern Illinois University/The Aspen Institute. Like the Brazilian schools studied, the U.S. institutions varied considerably. The Olin School and the Aspen institute are clearly elite institutions. Olin routinely ranks among the top 20 U.S. business schools and the Aspen institute is a one of its kind center of humanistic executive education renowned throughout the world. The University of Kentucky is the most prominent university in the state and its business school has been provided with special funding to increase its status to that of a major national player. The University of Louisville is a selective private university whose alumni are well represented in the regional elites. SIU and Purdue North Central are middle class institutions that cater to first generation college students and blue collar families.

Data Analysis. A total of 17 hours of audiorecorded interviews were obtained in Brazil and 9 hours in the U.S. The Portuguese language interviews were transcribed and content analyzed using the NVivo 8 software program. This software helped to seek, first of all, the exhaustive generation of mutually-excluding categories (Miles \& Huberman, 1994) represented by a set of codes that refer to various converging impressions, critiques and factors regarding the theme. From this set of codes, described as first order codes, proximity cause and effect relationships were established that made it possible to identify second-order categories based on more encompassing descriptions (Gioia \& Thomas, 1996). These in turn became the main themes (key dimensions) identified in the Brazilian sample. The U.S. interviews were content analyzed manually. Due to the smaller number of US interviews and prohibitive cost of transcribing and inputting the English language results we did not undertake NVivo analysis of the North American sample; neither did we undertake a mechanical analysis of the U.S. data because the N-Vivo themes we obtained in Brazil were so similar to those obtained from a very rudimentary manual analysis. Without any mechanical data analysis, even the most cursory review of the audio recordings reveals that the major themes that emerged in the interviews from the two countries were quite different. We catalogue and discuss the major differences we found below. 


\section{Results}

\section{Leadership from the Brazilian scholars' perspective}

Either a manual or N-Vivo content analysis uncovered five broad themes: The construct's current stage: exhaustion and crisis; Leader development versus management normalization; The notion of leader versus manager; Competence and leadership development; and Developing leaders for the $21^{\text {st }}$ century.

\section{The construct's current stage: exhaustion and crisis}

The Brazilian professors and researchers whom were surveyed saw a great need for new theoretical, methodological and conceptual approaches to analyze the phenomenon in its current state. According to several interviewees, leadership is currently a construct undergoing a crisis that stems from the exhaustion of its theoretical-conceptual matrices. According to the interviewees, this exhaustion discourages the development of new research and the establishment of systematic research programs which could inform innovative business practices. The Brazilian scholars claim that due to the lack of serious scholarly research, there is a proliferation of so-called self-help literature as well as solutions that are merely prescriptive and normative and lacking in intellectual heft and rigor. This, in turn, reinforces disillusionment, low academic status and again discourages new and innovative research in the field.

Although the last twenty years have witnessed the development of several new theoretical approaches to leadership, there is a perception that the most substantive research and the most significant theoretical contributions to the theme were concentrated between 1940 and 1970, that is, during the period that encompassed the formulation and dissemination of great theories, such as the trait, behavioral and situational approaches. After this period, according to a large number of interviewees, little was developed that was effectively new. At most there is a reframing or re-reading of older approaches such as, for example, the current return to the traits perspective reframed under the rubric of managerial competencies. At the same time our Brazilian interviewees saw evidence of an apparent strengthening of the classic notion of the heroic leader through the current idolization of famous executives and politicians, as well as of fascination with the notion of the charismatic leader.

We also ascertained that there was a perception of a certain popularization or vulgarization of the construct, which was said to be characterized by common sense concepts that seek to explain everything although, actually, they explain little or very little in terms of organizational dynamics. According to the interviews, the multiple meanings, imprecise definitions and uncritical reincarnation of former theories that typify work in the area all make it difficult to identify the actual theoretical and empirical contributions made by the construct, thereby reinforcing the perception that much of what is published about the theme can be summed up as aspects that are warmed over and, often offer little consistency in theoretical terms. There was also ample perception that links to the consulting industry and to the North American-based management model prevent attention to core dimensions required for a broader analysis of the phenomenon, such as power and control. In the same vein, several interviewees viewed the entire field of study as excessively naïve and ideologically influenced.

\section{Leader development versus management normalization}

Management normalization, as a counterpoint to differentiation, was also identified as a relevant aspect of the contemporary academic debate on leadership. If we make an analogy to a normal distribution curve, then the role of the leader as a change and transformation agent is commonly called working the tails of the normal curve. The role of the manager, by contrast, seeks to control organizational behavior by limiting individual behavior, attitudes and skills so that they fit into the 
normal curve. This drive for managerial control leaves ever less room for leadership behaviors like those celebrated in the popular and academic imagination, i.e. leadership that transforms, that overcomes existing standards and norms, or that moves beyond.

In other words, at the same time when an organizational discourse is disseminated that values as the core attributes of contemporary leadership discourse such as innovation, autonomy, individual initiative and the capacity to have a systemic view that can disturb the internal environment of the company, those who do not fit the rules, values and the competencies prescribed will usually be excluded or seen in a bad light. Traditional managerial controls will favor profiles that are better adjusted to the center of the normal curve. This contradiction is seen as one of the major challenges for leadership in the mid to long term.

\section{Leader versus manager}

The prevalence of the debate that surrounds the meanings attributed to the words 'leader' and 'manager' are directly linked to the matter of management normalization mentioned above. The Brazilian academics interviewed saw a clear link between the two issues and saw this tension as an essential definitional matter. There was considerable ambivalence about the degree to which both roles can be exercised by the same individual.

This tension surfaced in practically all of the Brazilian interviews, although it sometimes arose in reference to leadership development rather than leadership theory per se. There was a perception that current leadership development methodologies actually apply to management development and have little to do with leadership development itself.

At the same time, there was considerable doubt as to how interested organizations really are in developing leaders. This was seen as stemming from a thorny set of tensions surrounding daily existence in organizations. The objectives by which managers are evaluated are typically derived from the immediate operational needs of the organization and stem from the fact that the objectives that are set for managers will derive from present needs and not from future desired states. Managers are also called on to negotiate political conflicts in the organization while keeping daily operations on track. These functions are typically quite divorced from the more symbolic, visionary and strategic roles attributed to leaders. Such functions are hard to measure and monitor and when they fail, there is no immediate crisis as when management fails. Thus the attention that leaders dedicate to attempting to inspire subordinates, stimulate creative behavior, and reward superior performance is likely to incur costs in terms of short term volatility in the managerial indicators of operational predictability, conflict suppression and short term compliance. Leaders' relationships with their subordinates and colleagues are likely to be intense, their daily work environment will be habitually chaotic, and if organizational structure and capabilities do not favor this kind of behavior, the natural pressure toward managerial normalization will likely drive out leader type behaviors. Perhaps because of their perceptions of these tensions, the Brazilian academics expressed higher interest in and motivation for situational theories of leadership:

In this view (i.e., that leadership is highly situational) it can be argued that hierarchical position and the tasks set out by formal authority will not guarantee the emergence of a leader. Managers will become leaders when their power is legitimized by the group. Along the same lines, leadership development might ideally involve learning about when and how managers can step into the role of leaders. A leader cannot be appointed as such before there is a demand from the organizational system, since a leader will emerge from the managerial role to cause a change in the relationship between the company and its environment. Thus, manager and leader are two distinct functions that, nonetheless, can be carried out by a single person.

Our informants tended to see the leader-manager dichotomy as useful for understanding such different roles, but believed that due to the application of situational approaches and other management tools, in the end companies will assess individuals with the expectation of their 
exercising both functions, although there will be an overvaluation of the leader in relation to the manager.

Lastly, some of the interviewees defended the idea that a manager's role is at least as important as a leader's, and that executives should rethink their current overemphasis on leadership. Demanding both leadership and management functions from the same person might not be the most appropriate thing to do. As pointed out by one of the interviewees:

\begin{abstract}
"When I teach I tell my students something like this: stop thinking that if you are not leaders you will be letting the company down, because if you, as managers, can create and maintain an environment that is favorable to the emergence of leaders you will actually be delivering to the company the best conditions possible, because a leadership environment is a learning environment”. (Interviewee)

"Thus, the figure of the manager exists to create the setting within which people make efforts to produce the results we call work. That is, it is the manager's job to say that this here is an IT department, that this here is an energy company, this here is a communications company, this here is an energy company, this here is an education company, and this here is an IT department within an energy company, or this here is an HR area. That is, it is the manager who will set up this overall configuration. And if this should not happen, people in the setting will not be able to put up with the chaos of a lack of meaning, and they will come together for other reasons". (Interviewee)
\end{abstract}

\title{
Competence and leadership development
}

The development of competencies that are needed to develop leaders was also very much emphasized in the interviews as a relevant issue. Some cases of organizations that were successful because they integrated strategy, organizational competencies, individual competencies and leadership were highlighted:

\footnotetext{
"I believe in leadership development just as I believe in competence development, and so to me the road to leadership development also deals with understanding how you develop competencies within an organization. Take the case of General Electric which is very well known throughout the world for developing leaders. Many people believe that it is the corporate university that does it. Actually, the corporate university does play a role, but the great combination that brought success to GE was that it actually has a methodology for developing leaders. I mean, there are management policies and human resources policies that for over 100 years have always privileged meritocracy". (Interviewee)
}

When the respondents spoke of leadership as related to personal competence, the leadership role was seen very broadly as containing as cutting across several levels of analysis. Leader competencies were seen to include such diverse functions as implementing corporate strategy, being the guardian of intergroup processes, maintaining organizational routines, and controlling the complexity that is inherent to groups so that their internal processes do not acquire dysfunctional tendencies. At the same time, they are responsible for encouraging cooperation among work groups through empathy and through incentives to draw out feelings, which will increasingly require what is known as emotional and social competencies.

\section{Developing leaders for the $21^{\text {st }}$ century}

The Brazilian interviewees exhibited a sharp, if critical, awareness of current leader development issues. Special attention was directed at issues that stem from the baby boomer generation being near retirement, the problematics of executive succession, especially in family businesses, the so-called talent war, and the tradeoffs between developing leaders internally or seeking them out them in the market. Of these issues, most attention was dedicated to the value structure of the coming generation and its relation to leadership development, and the efforts of firms to socialize new hires, especially highly qualified new hires, into the cultural and leadership systems.

There was greatest concern about the young people who were born between 1980 and 2001, the so-called Y Generation or Millennial, to whom a differentiated set of values and expectations as 
regards work is attributed. The $\mathrm{Y}$ generation is a generation made up of young people who are commonly regarded as being oriented to their own careers and to a quest for meaning in the tasks they carry out. Interviewees affirmed that current management models would not be able to effectively respond to the characteristics of this new generation, thus creating a variety of challenges as this group begins to occupy senior positions in organizations.

Also in relation to these intergenerational issues, interviewees were interested in and generally critical of the nature and dynamics of managerial trainee programs. Some saw such programs as leading young people to identify with their superiors and to reproduce this identification in their subordinates. Especially highly qualified young trainees at large corporations were seen as being subjected to the social processes described by Pagès, Bonetti, De Gaulejac and Descendre (1987). These include deterritorialization and de-identification, thus reinforcing a socialization cycle that aims at acculturation and conformity:

\begin{abstract}
"These programs are very sophisticated. On the one hand you lose the values that relate to the family because you do not live with them anymore. You do not have the chance to personally talk with them-they only visit once a month on the weekend. In this case it is necessary, because in the absence of family they have to identify with someone. They identify with their organization, of course. In this way the company destroys the trainee's identity, to use a strong word, which technically they call deidentification. My link to the world becomes the organization because I have internalized these values very strongly. It is a projection, psychoanalytically speaking, and the organization has always been something abstract. And so it needs someone to represent its identity and this someone becomes the leader. And so what leader becomes conceptualized as the guy who manages to bring out high performance in people because they are led by him. But if he leaves the organization then productivity will usually drop. His subordinates will end up either leaving or changing jobs because they have lost their source of identity with the departure of the leader". (Interviewee)
\end{abstract}

Table 1 presents a summary of all the main themes and aspects associated with the leadership construct within the current context, as discussed above.

\title{
Table 1
}

The Main Aspects Associated with the Leadership Construct within the Current Context

\begin{tabular}{|c|c|c|}
\hline Key themes & Characteristics & Exemplary Quotes \\
\hline \multirow{3}{*}{$\begin{array}{l}\text { The current stage } \\
\text { of the construct: } \\
\text { exhaustion and } \\
\text { crisis }\end{array}$} & $\begin{array}{l}\text { Theoretical exhaustion of } \\
\text { the studies about } \\
\text { leadership and the return to }\end{array}$ & $\begin{array}{l}\text { "The construct is over. It seems that, suddenly, researchers } \\
\text { in this field have come to the conclusion that the subject } \\
\text { has been exhausted". (Interviewee) }\end{array}$ \\
\hline & $\begin{array}{l}\text { the traits, charisma and } \\
\text { heroic leadership theories }\end{array}$ & $\begin{array}{l}\text { "This is the kind of thing that has been vulgarized, but } \\
\text { vulgarized in the bad sense of the word. I mean, it is not } \\
\text { something that has been vulgarized in the meaning of being } \\
\text { disseminated thoroughly, but rather in the sense of a lack } \\
\text { of content. This is almost theoretical mediocrity". } \\
\text { (Interviewee) }\end{array}$ \\
\hline & & $\begin{array}{l}\text { "Now, what I find strange, but it is still consistent with this } \\
\text { theme of creating or re-creating administrative myths, is } \\
\text { the resurgence, a little bit if you want to make a theoretical } \\
\text { link, of the trait theory". (Interviewee) }\end{array}$ \\
\hline $\begin{array}{l}\text { Leadership } \\
\text { development } \\
\text { versus } \\
\text { management } \\
\text { normalization }\end{array}$ & $\begin{array}{l}\text { The implications of the } \\
\text { mechanistic characteristics } \\
\text { of management for the } \\
\text { emergence and retention of } \\
\text { leaders }\end{array}$ & $\begin{array}{l}\text { "I believe that the space is a little limited because the } \\
\text { company wants results, but it does not want you to disturb } \\
\text { it very much and to bring in much innovation. You are } \\
\text { going to threaten people and you are going to disturb them. } \\
\text { So firms want leadership, but within certain limits, within a } \\
\text { certain space". (Interviewee) }\end{array}$ \\
\hline
\end{tabular}




\section{Table 1 (continued)}

\begin{tabular}{ll}
\hline \multicolumn{1}{c}{ Key themes } & \multicolumn{1}{c}{ Characteristics } \\
\hline & \\
& \\
The Notion of & The relations between \\
Leader versus & $\begin{array}{l}\text { situational leadership and } \\
\text { prioritizing leaders over } \\
\text { manager }\end{array}$ \\
managers
\end{tabular}

"In the $21^{\text {st }}$ century organizations and executives will have to become really humble and recognize the possibility that control has been reduced by at least $80 \%$ of the levels of control that the $20^{\text {th }}$ century allowed. The leadership function as exercised by the executive, by the manager, will be one of disturbing the system, because organizations are no longer machines that you can control and they are now self-organized systems. They have their own lives". (Interviewee)

"If we go into a company and ask them what kind of approach they use for leadership, most of them will mention situational leadership. From my point of view I believe that this is very much linked to the question of operationalizing the application of all these assessment processes like the Balanced Scorecard, while taking this abstract, generic concept and turning it into something you can quantify, into something palpable or something that is measurable". (Interviewee)

"Thus, management is one thing and leadership is something else, and there is always greater status involved in relation to the leadership theme. Leadership is the rich cousin and management is the poor cousin, and everyone in the organization wants to be a leader and not a manager. And as I see it, what must be improved in organizations is the role of managers. We need greater professionalism in management". (Interviewee)

Competence and Leadership as the result of leadership individual knowledge, development skills and attitudes versus

"There are several processes within the group, several themes, several cycles that can be either virtuous or vicious, and the leader must coordinate these processes so that they do not become vicious ones". (Interviewee) substitutes

"The role of the ability to express feelings and empathy and to foster cooperation within work teams. And so this means that the guy would have to have the skills to encourage people to express their feelings and to develop these characteristics that are needed for cooperation within workgroups. It is obvious that this would be a type of leadership very much attuned to group contexts and dynamics". (Interviewee)

Leadership The challenges facing the development for management of new the $21^{\text {st }}$ century professional profiles, especially within the context of the so-called $Y$ Generation
"Organizations must pay attention to the fact that they are no longer the only owners of the system of careers and trajectory planning, because people are also planning their own careers". (Interviewee)

"Nowadays, management comes quickly into people's lives. I am from the days when it would take you 15 years' experience to become a senior analyst. Nowadays everyone is a manager after five years. And I have also noticed that many people who have no vocation to become a manager will end up being one by default. The rationale goes like this: I need to earn more and accomplish this challenge, and so I accept it because of the money. And then I will lose a good technician in exchange for a bad manager". (Interviewee)

Note. Source: Research data. 
The following section will present the perspective of the North American scholars as a counterpoint to the Brazilian findings.

\section{Leadership from the perspective of North American scholars: a counterpoint to the Brazilian findings}

The results of the interviews carried out with North American scholars point to significant differences in the way the two groups think. The most immediately apparent difference was the relative centrality of the study and teaching of leadership to the professional interests and identities of North American professors compared to the Brazilian scholars who were studied.

As an example, one of the North American scholars reported that he only teaches courses on leadership and that he was very successful at restructuring the MBA curriculum at his institution to accommodate his passion for the topic. He even managed to turn the theme into the core discipline of the program's final year, which, according to him, led it to its being an important factor in differentiating the program from other North American institutions. Another interviewee also occupies the position of academic vice president at his university and he also only teaches leadership. He too stresses that he has developed a specific program on leadership that is aimed at the best students at his institution. Another interviewee mentioned that he also has only taught leadership development disciplines in the MBA program at his institution in recent years, although he has published several books and scientific papers on other topics, mainly in the human resources field. This contrasts with what we observed among Brazilian scholars. Very few indicated that leadership per se was their main interest either in teaching or research.

We also noted that unlike the Brazilian scholars who were interviewed, the U.S. sample did not detect any sense of exhaustion or crisis in leadership studies. Almost all of the North American professors who were interviewed highlighted several recent theories on the theme, among which LMX Theory stood out. Although they varied in their assessment of different theories, the U.S. professors found that recent work includes credible empirical research that adds substantial cumulative value to the canons of leadership research. Several of them described and criticized the findings of recent research in detail, referring to specific articles that have been published in important international academic journals and stressing the fact that they use this recent research to structure the leadership courses they teach.

The conceptual and practical tension between the roles of the leader and manager, which emerged as an important theme for Brazilian academics did not appear to be as significant to their North American colleagues, with only one exception: one of the interviewees described the two roles as being fundamentally opposing forces, and made it clear that he judged leadership as superior to management. He designed a substantial portion of his course based on the distinction between leadership and management. Furthermore, this interviewee criticized various aspects of a good portion of current research on the theme by stressing that these would be management theories and not actually leadership theories. The other interviewees, however, showed much less motivation towards such a distinction, and argued that in most situations it is necessary to blend both roles.

Among the North American scholars who were interviewed there was less emphasis on the idea that current organizations require approaches to leadership that are substantially different from those of the last century. Once more, unlike from the Brazilian interviewees, the North American participants seemed more likely to identify specific aspects of management or leadership practice that could be adjusted to respond to specific technological or social changes instead of perceiving the need for a radical rethinking of leadership roles or organizational designs.

If a relatively greater interest and passion for leadership as an object of study on the part of North American scholars was the most immediately apparent difference between the two groups that were surveyed, the most significant, or at least the most interesting one, was the variability of definitions and approaches to the theme used by the North American scholars who were interviewed. There were almost as many definitions of leadership and approaches to teaching and developing 
leaders as there were respondents. We will illustrate below some of the most different approaches that were reported.

\section{The existential approach}

According to the professor and academic vice president who was interviewed, the notion of leadership is related to how to define and position a person as a citizen within human society, and it must be understood as being part of a person's actual essence and development as a human being within society. The syllabus of the leadership programs he teaches include over one hundred bibliographical sources, most of them from classic works in philosophy, political science, sociology and psychology. Most of this bibliography is used to support a leadership development strategy that consists of working on existential questions through seminars prepared by the students based on previous reading, weekly presentations of the readings, followed by questions based on the Socratic Method, and vigorous debate.

\section{The career trajectory approach}

Another approach involved the definition of leadership as closely aligned with organizational goals and associated it with the positive impacts on value creation within an organization. This perspective had very little in common with the existential dimension, and was much less concerned with the role or impact of individuals or of organizations on society. The interviewee, whose credentials include a doctoral degree in organizational psychology as well as over twenty years' experience in corporate human resources, believed that leadership development is a function of three factors: (a) career path, involving various and increasingly broader responsibilities; (b) the development of key professional relationships; (c) exposure to formal thinking on management. Of these three factors, career path was considered most significant, one which according to the interviewee is responsible for about $70 \%$ of a leader's development. In second place he points to professional relationships, which are responsible for $20 \%$, and finally, theoretical-formal training, which is responsible for $10 \%$. His research focus and approach to leadership development is highly centered on a diagnostic perspective that involves personal inventories and career analysis, coaching by colleagues, case discussions and, finally, limited theoretical teaching. Thus, while in the Existential Approach, presenting, formally analyzing and discussing ideas make up the main research and teaching strategies, in the Career Trajectory Approach this kind of debate and philosophical reflection has almost no role.

\section{The leader as puzzle solver approach}

Another definition of leadership that is distinct from the others likens leadership to putting a puzzle together. It has strong roots in experimental social psychology and its proponent offers a definition of leadership that is similar to that used in the Career Trajectory Approach, although it has different implications for leadership development. According to this professor, leadership is the capacity to influence others in favor of organizational goals. Although for him leadership is a relatively generic and broadly disseminated phenomenon, its practice varies substantially and systematically according to different situations. Therefore, the path to understanding and developing leadership passes through an extensive inventory of knowledge about a broad variety of collective situations, as well as experimental diagnoses that will simulate such situations.

He sums up this approach by stressing that human behavior is a function of interactions between the person and the situation. For example, when the discussion turned toward what he would do if he had $\$ 100,000$ to invest in leadership development and could invest it any way he wanted to, the interviewee could not suggest any answer until a specific organizational situation was hypothesized. For instance, when a call center context was suggested he was then able to identify a set of measures and activities; when a mobile phone sales department was mentioned, he suggested another set; and so on, successively. 


\section{The leader as a mediator/broker approach}

Another interviewee stressed that he used an approach that aims to detect relationships between leadership and social networks, and he emphasized the analysis of the configurations of relationships among groups or collections of actors so as to investigate the position of a certain individual and his perception as a leader within the network. This scholar states that a fundamental discovery he has made in his studies is that, habitually, leaders are perceived as such due to their skills at mediating or intermediating interests among different groups that are frequently at odds with each other. Another professor conceptualizes the leader in a similar way, although instead of focusing on the position of the actor within the network she analyzes the cultural and personal differences in distinct hierarchical positions, as well as the need for leaders to mediate the relationships among those that give orders and those that respond to them. Certainly it is not a coincidence that this researcher works at an institution whose historic mission is to train first generation managers at the beginning of their careers.

\section{Conclusions: the Study of Leadership as a Socially Constructed Field}

As we affirmed at the beginning of this paper, there is probably some intrinsic value for students of leadership in being aware of differences in approaches to the phenomenon in two different countries. However, taking the position in this paper that interpreting our results as manifestations of actors socially constructing and navigating similar but distinct institutional fields will be analytically more fruitful and intellectually more satisfying than a solely descriptive exercise, we chose Bourdieu's ideas as a useful theoretical reference point. Neither the scope of this exploratory study nor the space constraints of a journal article permit a thorough appreciation of Bourdieu's opus for an analysis of academic leadership thought in Brazil and the United States. It is nevertheless possible in conclusion to point toward ways that our understanding of leadership thought across nations may be enhanced by a constructivist perspective.

As a starting point, at the risk of belaboring the obvious, it seems clear that the objectivist or positivistic model of information generation and diffusion does not fit the data obtained from our interviewees. This becomes abundantly clear when we compare the structure and content of our literature review with the structure and content of our interview data. Our coverage of the evolution of leadership thought over the past 70 years is not radically different from that of any competent literature review on the topic that might appear in a scholarly article or graduate textbook. The schools of thought identified are the same, the major intellectual forces or movements that caused debates and transitions are the same, and our relative assessment of which theories are currently most successful would likely vary little from other authors. Despite this formal homogeneity in the "scientific" literature on the topic, virtually none of the 26 academics interviewed in either country conceptualized, researched or structured their approach to leadership in a manner that was clearly isomorphic with the pattern found in the formal literature.

Although some favored one of the recent theories more than earlier theories, none uncritically favored the most recent theories because they were new or dominant. None evaluated the comparative validity or utility of any theory using criteria or reasoning identical to that found in the formal literature. And no academic interviewed structured classes or recommended approaches to leadership development by employing the historical model presented in the literature in general. Rather, each selected some subset of ideas from the formal academic literature and advanced a position favoring some ideas and disfavoring others.

This kind of positioning vis-à-vis existing ideas is of course highly consistent with Bourdieu's thinking concerning the nature of fields, cultural capital and habitus. The same observation Bourdieu made regarding journalists could probably be applied to the academics we studied: "If I want to find out what one or another journalist is going to say or write, or will find obvious or unthinkable, normal 
or worthless, I have to know the position that journalist occupies in that space" (Bourdieu, 1998, p. 41).

The exact nature of that space or the field to which Bourdieu refers remains to be fully defined in future work, but our current research, coupled with constructivist concepts, provides some novel ideas about the nature of the social fields in which Brazilian and U.S. academics ponder the phenomenon of leadership. One clear difference between the Brazilian and North American fields would appear to be their degree of internal differentiation. We easily identified at least four quite different views of the nature of leadership and leader development among the 7 U.S. interviewees, while with more than double the number of respondents and the help of N-Vivo content analysis the Brazilian group was not highly demarcated by different epistemic or philosophical positions.

More than one of the U.S. professors' philosophical and pedagological postures seemed consistent with Bourdieu's thinking about how fields are stratified by economic and cultural capital. In some of his work, Bourdieu (1993, p. 38) posits a space in social fields that is differentiated by the juxtaposition of economic and cultural capital. His scheme places total capital on a vertical axis and proportion of cultural capital to economic capital on the horizontal axis to help describe one aspect of the field (Benson, 2006). This results in four general categories: high total capital of which a high proportion is cultural capital, low total capital of which a high proportion is cultural, low total capital of which a smaller proportion is cultural capital, and high total capital in which a larger proportion is cultural. The existential orientation was used at Aspen institute to instruct CEOs who were high on total capital with a somewhat smaller proportion of cultural to total - the evident intent being to bring the CEO's cultural capital more into line with his/her position as formal representative of the organization. It was also used with the elite students of a middle class institution to leverage their lower total capital by enhancing their already proportionally higher cultural capital. In contrast, the mediator approach was used effectively at a blue collar university with low cultural capital to increase the cultural capital of technically trained students and experienced supervisors so that they could understand the cultural worlds of higher level managers and lower level workers. The structure and content of both approaches was consistent with the cultural capital demands of their respective market niches.

Another somewhat paradoxical difference might be the apparently more even diffusion of the entire corpus of formal leadership theory among the U.S. interviewees. Despite the fact that they varied considerably in their personal positions, when asked to identify positive and negative points in existing thought, the U.S. respondents were generally more exhaustive in their comments, citing most or all of the current schools or trends. The Brazilian academics, in contrast, exhibited less variance in their philosophical and theoretical positioning, and were also rather uniform in mentioning and critiquing the same limited subset of theories in rather similar ways. This simultaneous high diffusion of standard information coupled with high differentiation in positions is typical of a highly institutionalized field (DiMaggio \& Powell, 1991).

It is possible that Bourdieu's ideas may point toward one explanation for the comparative higher differentiation of philosophical positions vis-à-vis leadership in the U.S versus the Brazilian interviews. A superficial but reasonably accurate summary of Bourdieu's explanation of habitus is that habitus is a function of a person's position in the field plus their individual trajectory. Our U.S. academics are more differentiated from their Brazilian colleagues both in terms of their class position and their personal trajectories. We found that the universities in which they teach are more highly differentiated in terms of prestige, salary and tuition than the Brazilian institutions. Their salaries varied from 75,000 to around 200,000 dollars per year. Their personal trajectories also appear to vary more. For instance, all 9 of the U.S. professors obtained their PhD from different universities in 7 different states. Of the 17 Brazilian professors, 10 obtained their doctorates in one of two states in Brazil and 7 received their doctorates from the same schools. There is also little differentiation in their salaries and typically little mobility between schools and regions. Until fairly recently, any college education was indicative of elite status, so there is as yet little distinction in prestige and market strategy from one university to another in our Brazilian sample. Taking these factors together, it would be surprising if the U.S. field were not more differentiated than the Brazilian field. 
Another dimension of Bourdieu's thought that may be relevant to our study is the degree of autonomy or heteronomy of the field of business education in Brazil and the U.S. (Bourdieu, 1993). In a recent application of the concept of field to higher education, Maton (2005) proposes two types of autonomy; positional and relational. Positional autonomy refers to the degree to which the dominant agents in a field have their origin in the field. For example, the recent tendency in some U.S. business programs to appoint a former executive rather than an academic as dean is an indication of erosion in positional autonomy. Relational autonomy refers to the degree to which a field's principles of hierarchization come from inside or outside the field. An example here again indicating anerosion in relational autonomy would be increasing concern with the employability of graduates, because universities have traditionally been concerned more with the enhancement of cultural rather than economic capital. Refraction involves rephrasing or reinterpreting debates or values from other fields using language or constructs unique to the autonomous field. So if, for instance, government policy emphasizes national competitiveness but debates in educational circles center on increasing the rigor of academic programs, refraction has occurred. Maton argues that the less the autonomy of a field, the less its major debates and conflicts involve the refraction of themes from other fields.

Utilizing the criteria advanced by Maton, it would appear that the North American field of business education has less autonomy than comparable Brazilian business education whether positional or relational autonomy is considered. Space will not permit a detailed comparative institutional analysis here, but two examples are suggestive. Not only do state and private universities in the U.S. have governing boards consisting of a variety of citizens from different professions, it is now very common for individual business schools and even departments of management to have their own advisory boards composed of prominent businesspeople and alumni. Similarly, a brief review of course and program descriptions of U.S. business programs reveals a strong managerial orientation in their discourse. Terms like efficiency, effectiveness, value added, competitiveness, and positive results are used without qualification or apology.

If one accepts the affirmation that Brazilian business education is less heteronomous, it follows unambiguously from Bourdieu's thought that debates and themes of discourse should be more refractive or less directly related to the concerns of other fields in the Brazilian interviews than in the American interviews. We are uncertain as to whether this is the case. Certainly, the Brazilian interviewees entertain a more critical posture toward other fields-organizations and managers, consultancies, and even the popular business press-than the U.S. respondents. However, refraction is not tantamount to criticism or rejection. Moreover, the Brazilian academics appeared to display a sharper awareness of current managerial issues such as generation $\mathrm{Y}$, increased dynamism in the business environment, elite trainee programs and the difficulty of attracting and retaining leaders, than did the U.S. academics. Furthermore, the centrality of the manager-leader dichotomy in the Brazilian interviews does not suggest refraction given that management versus leadership is a popular theme in the management and training fields.

This scenario becomes more complex when we consider the reaction of the Brazilian academics to orthodox current international or U.S leadership theory. There appears to be some fondness for the classical leadership theories accompanied by ambivalence vis-à-vis more recent approaches, particularly charismatic and transformational leadership. The interviewees themselves note that interest in managerial competence in Brazil appears to hark back to trait theory while attempting to sanitize or remove any heroic or charismatic vestiges. This shift from traits to competencies certainly could be seen as refraction, although the refraction is occurring vis-à-vis an international rather than a national field. Even here though, the repudiation of currently fashionable theories of U.S./international charismatic leadership is not a matter of refraction, but one of rejection. Our inquiry thus leads us to a point where analytical progress will require us not only to test the limits of objectivist thinking but also to challenge or extend Bourdieu's thinking. Is the critical posture we noted among Brazilian academics merely a cultural reaction to a legacy of colonialism and authoritarianism unrelated to the nature of the Brazilian academic field, or to Bourdieu's theories, or is our case one which roundly contradicts Bourdieu's ideas on autonomy and refraction? Or does the study of Brazilian leadership thought suggest rejection rather than refraction as an attribute of some autonomous fields that has not 
yet been recognized or explored? Such questions are beyond the scope of our present inquiry, but they show interesting potential for future research.

It would certainly be premature here to attempt to evaluate the merits of Brazilian academic thinking on leadership, but in closing we feel it would be useful, if not imperative, to speculate about some of the possible benefits and disadvantages of the types of fields we observed for progress in the theory and practice of leadership. The differentiated and heteronomous nature of the North American business education field seems to have permitted the development of a variegated and nuanced approach to leadership that fits with the perceived needs and demands of the varied constituencies and niche markets that American business programs serve. Paradoxically, the professors acting in this same field also seem to have been able to absorb and position themselves vis-à-vis a large and evolving body of formal thinking and research. At the same time, the U.S. sample's lack of critical insight and disinterest in or alienation from the interface between rapid societal change and leadership thought may be the price paid for a prosperous and differentiated intellectual field.

The less differentiated and heteronomous Brazilian business education field would seem to have the advantage of permitting a shared vocabulary and understanding of the construct and the diffusion of a strong critical perspective that provides future managers with a unique perspective from which to evaluate organizational and managerial systems. At the same time it might be argued that the field's low heteronomy results in relative isolation from managerial praxis. This isolation perhaps permits Brazilian researchers to identify stagnation and deficiencies in foreign theories but has not yet stimulated vibrant indigenous or local theories to challenge or take the place of the imported ones. Into this academic vacuum, a pastiche of less rigorous self help thinking has occupied the attention of Brazilian managers. It is probably a loss for all concerned that the same intellectual establishment that gave us Roberto Da Mata, Guerreiro Ramos and Sergio Buarque de Holanda, to name a few, has thus far, not developed its own theory of leadership.

\section{Received 13 April 2010; received in revised form 23 August 2010.}

\section{References}

Bass, B., \& Avolio, B. (1990). Transformational leadership development: manual for the multifactor leadership questionnaire. Palo Alto: Consulting Psychologist Press.

Benson, M. J. (2006). New explorations in the field of leadership research: a walk on the dark side of personality and implications for leadership (in)effectiveness (Unpublished doctoral dissertation), University of Minnesota, Saint Paul.

Bergamini, C. (1994). Liderança: a administração do sentido. Revista de Administração de Empresas, 34(3), 102-114.

Blake, R., \& Mouton, J. (1964). The managerial grid. Houston: Gulf Publishing.

Bourdieu, P. (1977). Outline of a theory of practice. Cambridge, UK: Cambridge University Press.

Bourdieu, P. (1993). The field of cultural production. Cambridge, UK: Polity Press.

Bourdieu, P. (1998). On television. New York: New Press.

Burns, J. (1978). Leadership. New York: Harper \& Row.

Burns, T., \& Stalker, G. (1961). The management of innovation. London: Tavistock Publications.

Carlyle, T. (1842). On heroes, hero-worship and the heroic in history. Berkeley: University of California Press. 
Dansereau, F., Graen, G., \& Haga, W. (1975). A vertical dyad linkage approach to leadership within formal organizations: a longitudinal investigation of the role making process. Organizational Behavior and Human Performance, 13(1), 46-78. doi:10.1016/0030-5073(75)90005-7

DiMaggio, P. J., \& Powell, W. W. (1991). The iron cage revisited: Institutional isomorphism and collective rationality in organizational fields. In W. W. Powell \& P. J. DiMaggio (Eds.), The new institutionalism in organizational analysis (pp. 63-82). Chicago: University of Chicago Press.

Fiedler, F. (1967). A theory of leadership effectiveness. New York: McGraw-Hill.

Gioia, D., \& Thomas, J. (1996). Identity, image and issue interpretation: sensemaking during a strategic change in academia. Administrative Science Quarterly, 41(3), 370-403. doi: $10.2307 / 2393936$

Glaser, B., \& Strauss, A. (1967). The discovery of grounded theory. Chicago: Aldine.

Gong, Y., Haung, J.-C., \& Fahr J.-L. (2009). Employee learning orientation, transformational leadership and employee creativity. Academy of Management Journal, 52(4), 765-778.

Graeff, C. (1983). The situational leadership theory: a critical review. Academy of Management Journal, 8(2), 285-291. doi: 10.1016/S1048-9843(97)90014-X

Graen, G. B., \& Uhl-Bien, M. (1995). Relationship-based approach to leadership: development of leader-member exchange (LMX) theory of leadership over 25 years: applying a multi-level multi-domain perspective. Leadership Quarterly, 6(2), 219-247. doi: 10.1016/10489843(95)90036-5

Grint, K. (2001). The leadership arts. New York: Oxford University Press.

Grint, K. (2005). Problems, problems, problems: the social construction of leadership. Human Relations, 58(11), 1467-1494. doi: 10.1177/0018726705061314

Hersey, P., \& Blanchard, K. (1969). Management of organizational behavior. Englewood Cliffs: Prentice Hall.

Hogg, R. (2001). A social identity theory of leadership. Personal and Social Psychology Review, 5(3), 184-200. doi: 10.1207/S15327957PSPR0503_1

Horner, M. (1997). Leadership theory: past, present and future. Team Performance Management, 3(4), 270-287. doi: 10.1108/13527599710195402

House, R. (1971). A path goal theory of leader effectiveness. Administrative Science Quarterly, 16(3), 321-328.

Howell, J. M., \& Shamir, B. (2005). The role of followers in the charismatic leadership process. Academy of Management Journal, 30, 96-112. doi: 10.1177/1742715005057235

Judge, T., \& Bono, J. (2000). Five-factor model of personality and transformational leadership. Journal of Applied Psychology, 85(5), 751-765. doi: 10.1037/0021-9010.85.5.751

Kark, R., \& Van Dijk, D. (2007). Motivation the lead, motivation to follow: the role of self regulatory focus in leadership processes. Academy of Management Review, 32(2), 500-528. doi: $10.1348 / 0963179042596441$

Kirkman, B. L., Chen, G., Farh, J.-L., Chen, Z. X., \& Lowe, K. B. (2009). Individual power distance orientation and follower reactions to transformational leaders: a cross-level, cross-cultural examination. Academy of Management Journal, 52(4), 744-764. 
Lindholm, C. (2009). Charisma. Oxford: Blackwell.

Ling, Y., Simsek, Z., Lubatkin, M. H., \& Veiga, J. F. (2008). Transformational leadership's role in promoting corporate entrepreneurship: examining the CEO-TMT interface university of Connecticut. Academy of Management Journal, 51(3), 557-576.

Higgs, M. (2003). Developments in leadership thinking. Leadership \& Organization Development Journal, 24(5), 273-284.

Martin, J. (2002). Organizational culture: mapping the terrain. Thousand Oaks, CA: Sage.

Maton, K. (2005). A question of autonomy: Bourdieu's field approach and higher education policy. Journal of Educational Policy, 20(6), 687-704. doi: 10.1080/02680930500238861

McGregor, D. (1966). Leadership and motivation. Cambridge: MIT Press.

Meindl, J. R., Ehrlich, S. B., \& Dukerich, J. M. (1985). The romance of leadership. Administrative Science Quarterly, 30(1), 78-102. doi: 10.2307/2392813.

Milagres, R. (2005). Competitividade na cadeia produtiva brasileira (Relatório de Pesquisa/2005), Belo Horizonte, MG, Fundação Dom Cabral.

Miles, M., \& Huberman, A. (1994). Qualitative data analysis. Cambridge: Cambridge University Press.

Nelson, R. E. (1993). Autority, organization and societal context in multinational churches. Administrative Science Quarterly, 38(4), 653-682.

Pagès, M., Bonetti, M., De Gaulejac, V. E., \& Descendre, D. (1987). O poder das organizações. São Paulo: Atlas.

Pfeffer, J. (1987). A resource dependence perspective on interorganizational relations. In M. S. Mizruchi \& M. Schwartz (Eds.), Intercorporate relations: The structural analysis of business (pp. 22-55). Cambridge, UK: Cambridge University Press.

Piccolo, R. F., \& Colquitt, J. A. (2006). Transformational leadership and job behaviors: the mediating role of core job characteristics. Academy of Management Journal, 49(2), 327-340.

Schein, E. (1992). Organizational culture and leadership. New York: Jossey \& Bass.

Schyns, B., \& Bligh, M. C. (2007). Introduction to the special issue on the romance of leadership. Journal of Applied Psychology, 56(4), 501-504. doi: 10.1111/j.1464-0597.2007.00301.x

Seters, D., \& Field, R. (1990). The evolution of leadership theory. Journal of Organizational Change Management, 3(3), 29-45. doi: 10.1108/09534819010142139

Shamir, B., House, R. J., \& Arthur, M. B. (1993). The motivational effects of charismatic leaders: a self-concept based theory. Organizational Science, 4, 577-594. doi: 10.1287/orsc.4.4.577

Stogdill, R. (1950). Leadership, membership and organization. Psychological Bulletin, 47(1), 1-14. doi:10.1037/h0053857

Stout, L. (2001). Leadership: from mystery to mastery. Stockholm: Riga Press.

Trice, H. M., \& Beyer, J. M. (1993). The cultures of work organizations. Englewood Cliffs: Prentice Hall.

Vroom, V., \& Yetton, P. (1973). Leadership and decision-making. Pittsburgh: University of Pittsburgh Press. 